\title{
Reproduction of Mothocya epimerica (Crustacea: Isopoda: Cymothoidae), parasitic on the sand smelt Atherina boyeri (Osteichthyes: Atherinidae) in Greek lagoons
}

\author{
Ioannis Leonardos ${ }^{1, *}$, Jean-Paul Trilles ${ }^{2}$ \\ ${ }^{1}$ Biological Applications and Technologies Department, University of Ioannina, 45110 Ioannina, Greece \\ ${ }^{2}$ Equipe Adaptation Ecophysiologique et Ontogenese, UMR 5000 (UM 2-IFREMER-CNRS), Universite Montpellier 2, \\ CP 092, Place E. Bataillon, 34095 Montpellier, Cedex 5, France
}

\begin{abstract}
The reproduction and growth pattern of Mothocya epimerica (Crustacea: Isopoda: Cymothoidae), a protandrous hermaphroditic gill parasite of Atherina boyeri (Osteichthyes: Atherinidae), were investigated in the Mesolongi and Etolikon lagoons. The parasite shows an extensive reproductive period. Gravid females were found between April and November, and juveniles between May and December. M. epimerica grew allometrically (slopes of the total weight-total length regressions were $>3$ ). Females were significantly heavier than males. The relationship between number of eggs or mancas larvae (F) and total length (TL) was investigated in gravid female parasites in which the marsupium was still closed; the relationship was clearly curvilinear: $F=$ $0.128 \mathrm{TL}^{3.18}$. The number of eggs or mancas larvae held in the marsupia of females increased proportionally with female length, varying from 39 in an isopod of $6.3 \mathrm{~mm}$ length to 158 in one of $8.5 \mathrm{~mm}$ length. The average number of eggs or mancas larvae was $76.70 \pm 27.8$.
\end{abstract}

KEY WORDS: Mothocya epimerica $\cdot$ Isopoda $\cdot$ Cymothoidae $\cdot$ Atherina boyeri $\cdot$ Parasites $\cdot$ Lagoons Reproduction

\section{INTRODUCTION}

Elsewhere (Leonardos \& Trilles 2003) we reported the occurrence and the effect of Mothocya epimerica on Atherina boyeri in the Mesolongi and Etolikon lagoons. It was found that the presence of the parasite did not have a significant effect on the host's body condition, e.g. the length-weight relationship, gonadosomatic index, or hepatosomatic index. It was proposed that the physiological cost of this infection does not constitute a serious threat to individual host survival.

Mothocya epimerica (Crustacea: Isopoda: Cymothoidae) is a parasite of the branchial cavities, as well as the oral cavity, of sand smelt, a fish belonging to the genus Atherina (Osteichthyes: Atherinidae) (Montalenti 1948, Trilles 1968, 1994, Bruce 1986, Bello et al. 1997). M. epimerica is a protandric hermaphrodite isopod. The male phase continues through several additional moults until it is transformed into a functional female and begins to produce eggs (Trilles 1968, 1969, 1994, Sindermann 1990, Grabda 1991, Leonardos \& Trilles 2003). The presence of mature females inhibits further development of males in their vicinity.

Mothocya epimerica is found in the Atlantic Ocean and in various areas of the Mediterranean Sea, including the Black Sea. In the Adriatic Sea, presence of the species has been reported in the Lesina lagoon (Bello et al. 1997) and in several places along the Croatian coast (Radujkovic et al. 1984, Trilles 1994). Information regarding the biology of $M$. epimerica is somewhat scarce (Trilles 1964a,b, 1968, 1969, 1991, 1994, Bello et 
al. 1997, Leonardos \& Trilles 2003), and little is known about the details of its life history.

The host (Atherina boyeri) is a small pelagic teleost fish that spends its entire life in lagoons. Sand smelt has a relatively high commercial value; its average price on the Greek market is approximately 4 Euros $\mathrm{kg}^{-1}$. Moreover, the host is an important forage fish for larger predators in the lagoonal system. Aspects of the life history of $A$. boyeri have been recorded for various areas of the Mediterranean (Kohler 1976, Palmer et al. 1979, Gon \& Ben-Tuvia 1983, Palmer \& Culley 1983, Henderson \& Bamber 1987, Bamber \& Henderson 1988, Fernandez-Delgado et al. 1988, Creech 1992, Leonardos \& Sinis 2000, Leonardos 2001).

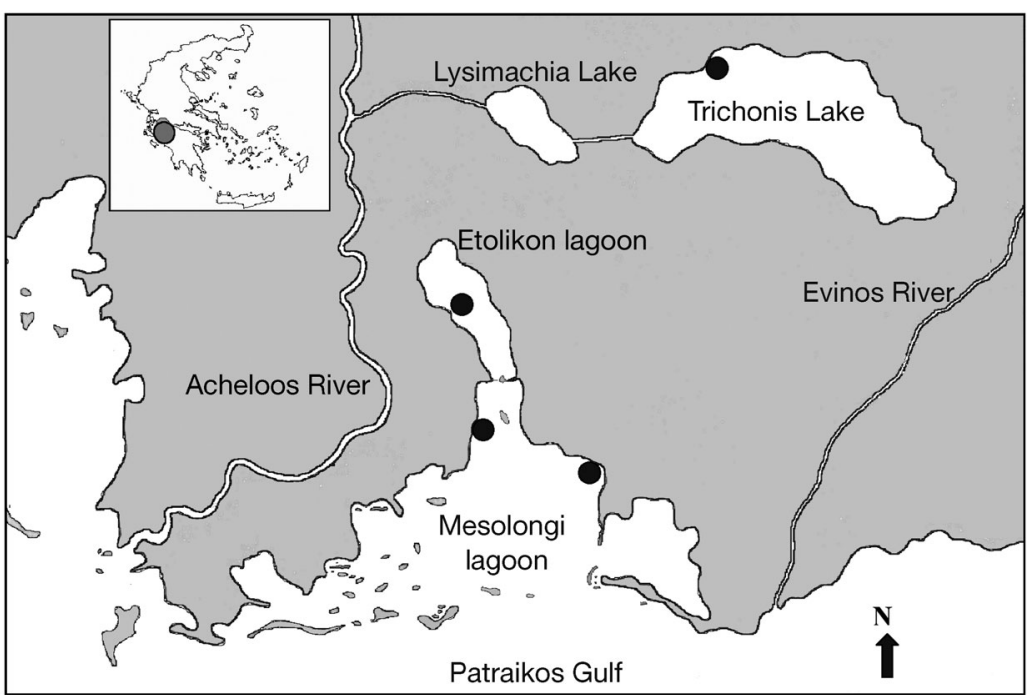

Fig. 1. Map of the Mesolongi and Etolikon lagoons, showing the 4 sampling stations

The reproductive cycle of the parasite is closely related to the life cycle of the host, due to the fact that most of the parasite's life cycle is closely synchronized with the host's life cycle. In the present work, the reproduction of Mothocya epimerica was studied by means of surveying the parasites on Atherina boyeri.

\section{MATERIALS AND METHODS}

The study was conducted in the Mesolongi and Etolikon lagoonal systems $\left(38^{\circ} 15^{\prime}\right.$ to $38^{\circ} 30^{\prime} \mathrm{N}$ and $21^{\circ} 05^{\prime}$ to $21^{\circ} 35^{\prime} \mathrm{E}$ ) (Fig. 1), which are among the largest in the Mediterranean, with a surface area of about $150 \mathrm{~km}^{2}$. Samplings were carried out at monthly intervals during the period from April 1989 to June 1990.

In order to study the reproduction of the parasite, as well as the relationship between host and parasite, 4 sampling stations were chosen. The first sampling station was in the Trichonis Lake, where a very abundant landlocked population of sand smelt exists. This population arrived in the lake from the lagoonal system and the adjusted areas, passing through the Acheloos River and neighboring channels (Leonardos 2001) (Fig. 1). The second sampling station was on the west side of the Etolikon lagoon. The third sampling station was northwest of the Mesolongi lagoon. The fourth sampling station was in the east of the Mesolongi lagoon, an isolated area where saltworks operate, resulting in salinity values of $>40$ psu for most of the year.

A beach seine was used with mesh size of $2.5 \mathrm{~mm}$, length of $15 \mathrm{~m}$ and height of $1.5 \mathrm{~m}$ at the edges and

$2 \mathrm{~m}$ in the center, terminating in a sack with a diameter of $1.5 \mathrm{~m}$ and length of $3 \mathrm{~m}$. Sand smelts and parasites were killed and preserved in $10 \%$ buffered formalin. During the sampling, water temperature (Fig. 2), salinity and dissolved oxygen were measured.

The mouth and branchial cavities of each fish were examined under a dissecting stereomicroscope. The parasites on each fish were numbered, sexed, weighed (to the nearest $0.1 \mathrm{mg}$ ) and measured (total length, to the nearest $0.1 \mathrm{~mm}$ ).

The relationship between parasite total length and parasite total weight was examined for males, females and both sexes combined, and the slopes of the equations were compared using an analysis of covariance (ANCOVA) (Zar 1999).

The relationship between number of eggs or embryos contained in the marsupium of a female parasite and their total length was investigated by studying the 'fecundity' of 44 gravid females whose marsupia were still closed.

Five stages of females were identified: (1) Nongravid females, with no eggs visible in the peraeon. (2) Gravid females with eggs visible in the peraeon. (3) Gravid females in which the peraeon is swollen and occupies about $1 / 3$ to $2 / 3$ of the ventral area. In this stage, eggs have still not been laid in the marsupium. (4) Gravid ovigerous females with the marsupium filled by newly laid eggs. In this stage a large perivitelline space occurs in the eggs. (5) Gravid ovigerous females with the marsupium still closed and filled with mancas before release. During this stage the marsupium is often open with only a few embryos. 


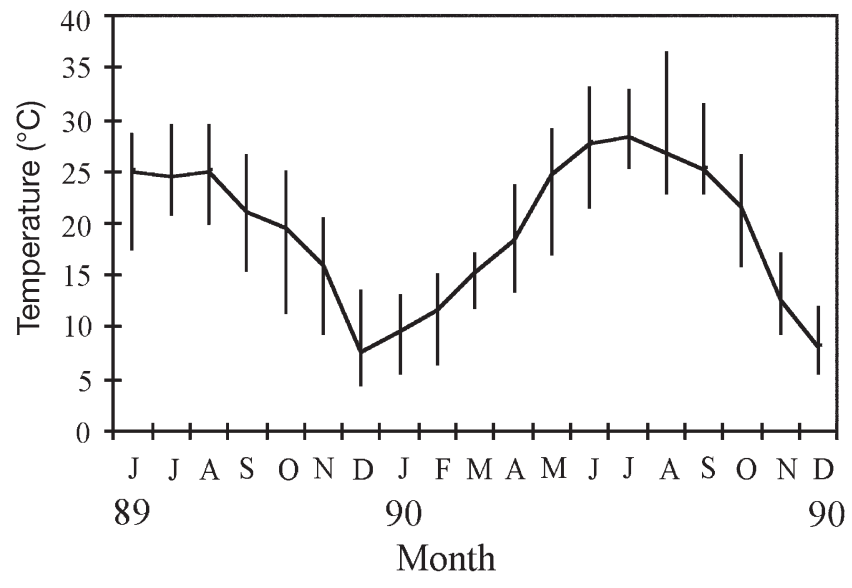

Fig. 2. Monthly variations of the water temperature $\left({ }^{\circ} \mathrm{C}\right)$ in the Mesolongi lagoon

\section{RESULTS}

Parasites were found at the second (Etolikon lagoon) and third (Mesolongi lagoon) sampling stations. The samples from these 2 sampling stations were combined. This was due to the fact that no statistically significant differences were found between the 2 sampling stations relating to the prevalence percentage and the lifehistory parameters of the parasite. As previously specified, the relationship between parasite total length (TL) and parasite total weight (TW) was studied for males, females and both sexes combined (Fig. 3). It was found that parasite growth is allometrically positive. The equations of total length-total weight regressions, calculated after log transformation, were: for males, TW = $9.78 \times 10^{-6} \mathrm{TL}^{3.85}\left(\mathrm{~N}=178, \mathrm{R}^{2}=0.82, F=800, \mathrm{p}<0.001\right.$, confidence limits of slope 3.58 to 4.12$)$; for females, $\mathrm{TW}=6.12 \times 10^{-6} \mathrm{TL}^{4.36}\left(\mathrm{~N}=289, \mathrm{R}^{2}=0.87, F=1990, \mathrm{p}<\right.$ 0.001 , confidence limits of slope 4.17 to 4.55 ); and for

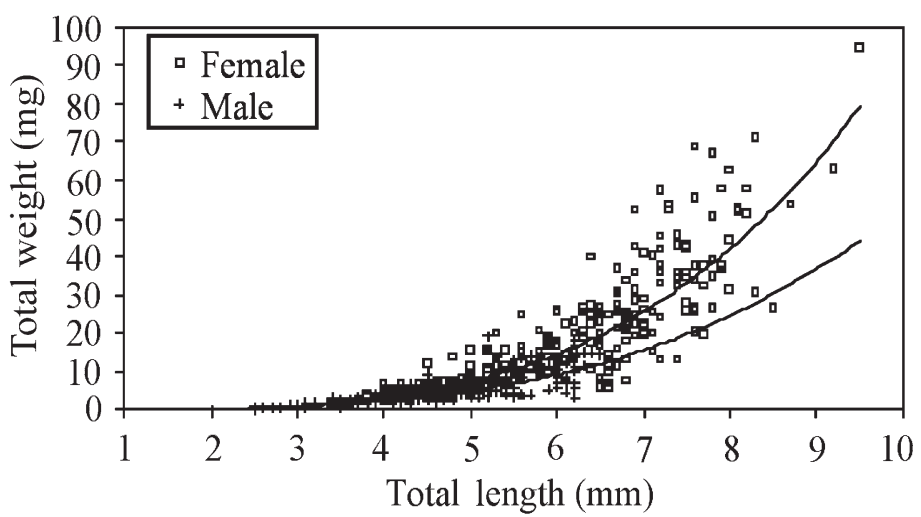

Fig. 3. Total length-total weight relationships of male and female Mothocya epimerica on Atherina boyeri from Mesolongi lagoon both sexes combined, TW $=6.40 \times 10^{-6} \mathrm{TL}^{4.25}(\mathrm{~N}=467$, $\mathrm{R}^{2}=0.85, F=2673, \mathrm{p}<0.001$, confidence limits of slope 4.09 to 4.42 ). The slopes of the separate equations were compared using an ANCOVA. It was found that the slope is higher for females (ANCOVA, $F=10.020$, $\operatorname{df}(1,464), p=0.001)$.

The number of eggs or embryos held in the female marsupium ( $F$, fecundity) ranged from 39 (in a female of $6.3 \mathrm{~mm}$ ) to 158 (in a female of $8.5 \mathrm{~mm}$ ), with a mean $( \pm \mathrm{SD})$ value of $76.70 \pm 27.8$ eggs. However, most of the gravid females were found with their marsupium open, enclosing a number of embryos. The relationship between number of eggs or embryos held in the female marsupium (F) and total length (TL) was suitably described by the equation: $\mathrm{F}=0.128 \mathrm{TL}^{3.18}\left(\mathrm{~N}=44, \mathrm{R}^{2}=\right.$ 0.68, p < 0.001) (Fig. 4). Moreover, the relationship between the fecundity and total weight was well described by the equation: $F=758.58 \mathrm{TW}^{0.76}(\mathrm{~N}=44$, $\mathrm{R}^{2}=0.62, \mathrm{p}<0.001$ ) (Fig. 5).

Gravid females were found mainly during the period from April to November, whereas juveniles were found from May to December. The above observations point out that reproduction takes place mainly between spring and late autumn (Fig. 6). However, 2 gravid females were found with the marsupium still closed, but filled with eggs. Contrary to in other months, male parasites in the December and January samples were more numerous than female parasites.

\section{DISCUSSION}

The absence of parasites from the 2 sampling stations Trichonis Lake (freshwater) and Mesolongi lagoon (saltworks) suggests that the parasite dies and

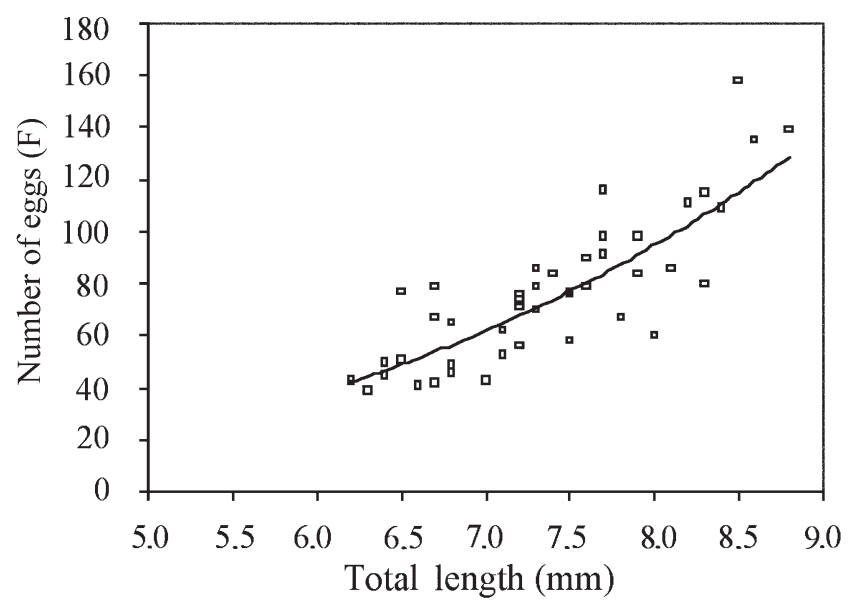

Fig. 4. Mothocya epimerica. Relationship between the number of eggs or embryos (fecundity) versus total length of the female specimens on Atherina boyeri from Mesolongi and Etolikon lagoons 


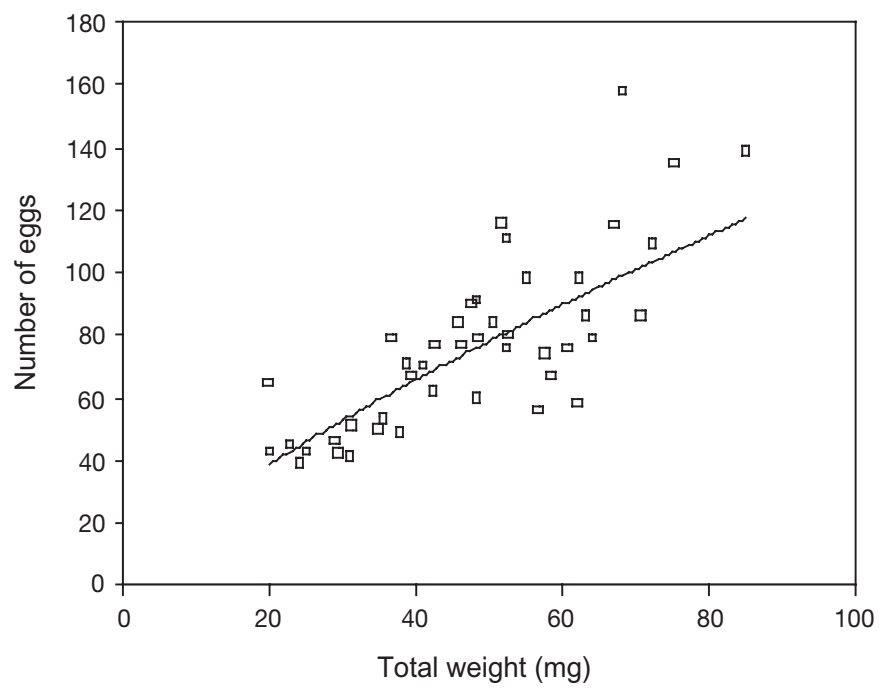

Fig. 5. Mothocya epimerica. Relationship between the number of eggs or embryos (fecundity) versus total weight of the female specimens on Atherina boyeri from Mesolongi and Etolikon lagoons

cannot follow the host during its movement in freshwater or in the saltworks.

Many aspects of the reproductive strategy of Mothocya epimerica are still unknown. According to Marks et al. (1996), cymothoids produce a small number of eggs per female. $M$. epimerica parasitizing sand smelt in the 'Etang de Thau' (France) was found by Trilles (1968) to produce $80-90$ to $180-230$ (in the biggest females) eggs. Bello et al. (1997) have found that $M$. epimerica on sand smelt in Lesina lagoon (Italy) produce an average number of 164.3 eggs. During this study, it was found that female parasites produce a considerably smaller number of eggs (76.70 eggs per female). A possible explanation for the above is given by Williams \& Williams (1985), who report that female cymothoids push larvae out of their marsupia as a response to capture.

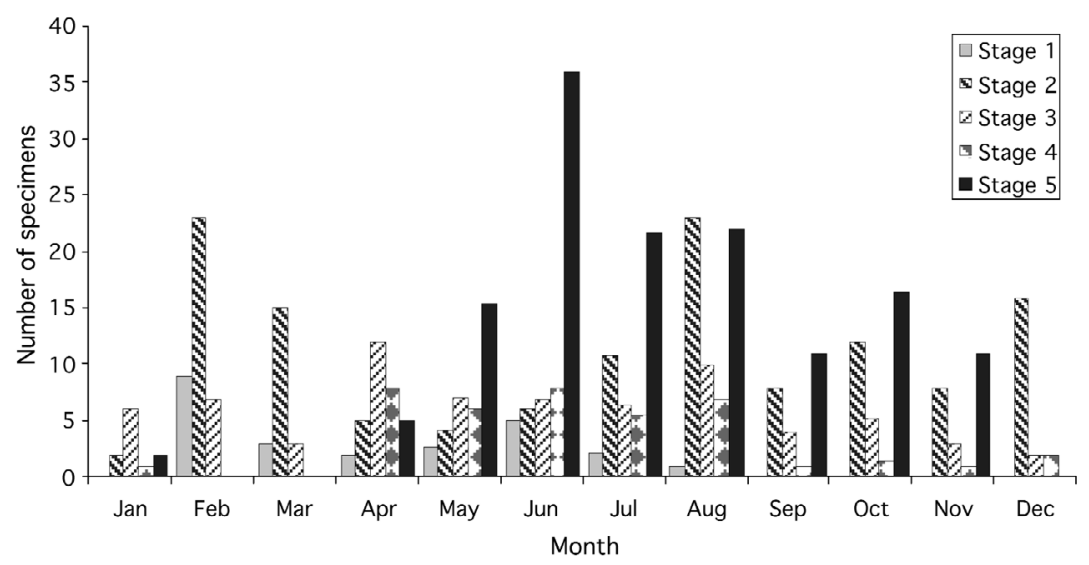

Fig. 6. Mothocya epimerica. Maturity stages of female specimens during the year
The populations of Mothocya epimerica from the Mesolongi and Etolikon lagoons produce fewer eggs in comparison to that from the Lesina lagoon and the 'Etang de Thau'. Furthermore, Leonardos \& Trilles (2003) reported that the populations from the Mesolongi and Etolikon lagoons show the highest degree of prevalence in the Mediterranean Sea. It seems, therefore, that the above is characteristic of the parasite in the eutrophic and warmer Mesolongi and Etolikon lagoons, where its prevalence is higher than in other lagoons and ponds, such as the 'Etang de Thau', but its fecundity is lower.

During this study, many gravid females were found with their marsupia open and enclosing various numbers of embryos. It appears that the female produces several broods. According to Brusca (1981), in cymothoid species, where the adult female feeds on the host, the females are able to produce more than 1 brood of mancas. Bello et al. (1997) suggest that reproduction of Mothocya epimerica is repeated at intervals of about 2 mo. Williams \& Williams (1982) suggested that female $M$. bohlkeorum produce multiple broods, live for a long period of time with the host, and grow as the host grows.

The results from studying the presence of gravid females and larvae throughout the year (Fig. 6) suggest that reproductive activity continues for most of the year. Bello et al. (1997), in the case of the Lesina lagoon, and Trilles (1968), in the case of the 'Etang de Thau', have found that the reproductive activity of the parasite decreases or is interrupted during the winter months, while in contrast it is more intense during the summer months. Colorni et al. (1997) studied the life cycle of the cymothoid Livoneca sp. and found that the lack of significant seasonal changes in the high temperature of the water allows the reproductive activity of the parasite to continue throughout the year. Probably, the relatively warmer winter in western Greece and the great depth $(33 \mathrm{~m})$ of the Etolikon lagoon, which is connected with the Mesolongi lagoon, where the temperature of the water remains relatively high even during the winter (Fig. 2), make it possible for the parasite to reproduce for such an extensive period. In the Etolikon lagoon, at the isobath contour line of $15 \mathrm{~m}$, the temperature of the water remains $>14.5^{\circ} \mathrm{C}$ during the entire year, while at the isobath contour line of $10 \mathrm{~m}$ (where the dissolved oxygen concentration exceeds $6 \mathrm{mg} \mathrm{l}^{-1}$ during winter) it remains $>9.6^{\circ} \mathrm{C}$ (Danielidis 1991). With the arrival of winter, fish that live in the lagoonal system abandon the shallow 
parts and migrate to deeper waters (mean depth $12 \mathrm{~m}$, maximum depth $33 \mathrm{~m}$ ) and to the warmer Etolikon lagoon.

The fecundity of the parasite is limited by the relatively small size of its peraeonal cavity, its rather large eggs and the small branchial cavity of the host. This fact is counterbalanced by the repeated reproductive periods of the parasite and permits the parasite to increase its individual fecundity.

Acknowledgements. The authors would like to thank Mrs. A. Kokkinidou, S. Kapetanakis and K. Maltezos for field work assistance, and F. Vorinakis, G. Lazarakis and E. Sfakaki for their help in the laboratory. Dr. V. Moutsaki is thanked for linguistic and technical assistance during preparation of the manuscript. Moreover, the authors would like to thank Prof. Z. Kabata and the anonymous referees for reviewing the manuscript and for their valuable comments.

\section{LITERATURE CITED}

Bamber R, Henderson PA (1988) Pre-adaptative plasticity in atherinids and the estuarine seat of the teleost evolution. J Fish Biol 33:17-23

Bello G, Vaglio A, Piscitelli G (1997) The reproductive cycle of Mothocya epimerica (Isopoda: Cymothoidae) a parasite of the sand smelt, Atherina boyeri (Osteichthyes: Atherinidae), in the Lesina Lagoon, Italy. J Nat Hist 31: 1055-1066

Bruce NL (1986) Revision of the isopod crustacean genus Mothocya Costa, in Hope, 1851 (Cymothoidae: Flabellifera), parasitic on marine fishes. J Nat Hist 20:1089-1192

Brusca RC (1981) A monograph on the Isopoda Cymothoidae (Crustacea) of the eastern Pacific. Zool J Linn Soc 73: 117-199

Colorni A, Trilles JP, Golani D (1997) Livoneca sp. (Flabellifera: Cymothoidae), an isopod parasite in the oral and branchial cavities of the Red Sea silverside Atherinomorus lacunosus (Perciformes, Atherinidae). Dis Aquat Org 31: $65-71$

Creech S (1992) A study of the population biology of Atherina boyeri Risso, 1810 in Aberthaw Lagoon, on the Bristol Channel, in South Wales. J Fish Biol 41:277-286

Danielidis D (1991) A systematic and ecological study of diatoms in the lagoons of Messolongi, Aitoliko and Kleissova. PhD dissertation, University of Athens (in Greek)

Fernandez-Delgado C, Hernando JA, Herrera M, Bellido M (1988) Life history patterns of the sand smelt Atherina boyeri Risso, 1810 in the estuary of the Guadalquivir River, Spain. Estuar Coast Shelf Sci 27:697-706

Gon O, Ben-Tuvia A (1983) The biology of Boyer's sand smelt, Atherina boyeri Risso, in the Bardawil Lagoon on the Mediterranean coast of Sinai. J Fish Biol 22:537-547

Grabda J (1991) Marine fish parasitology, an outline. PWN, Polish Scientific Publishers, Warsaw

Henderson PA, Bamber R (1987) On the reproductive biology of the sand smelt: Atherina boyeri Risso (Pisces: Atherinidae) and its evolutionary potential. Biol J Linn Soc 32:395-415

Kohler A (1976) Observations biologiques et biometriques sur Atherina boyeri Risso dans l'etang du Prevost a Palavas
(Herault). Vie Milieu 26:157-174

Leonardos I (2001) Ecology and exploitation pattern of a landlocked population of sand smelt, Atherina boyeri (Risso, 1810), in Trichonis Lake (western Greece). J Appl Ichthyol $17: 262-266$

Leonardos I, Sinis A (2000) Age, growth and mortality of Atherina boyeri Risso, 1810 (Pisces: Atherinidae) in the Mesolongi and Etolikon Lagoons (W. Greece). Fish Res 45: 81-91

Leonardos I, Trilles JP (2003) Host-parasite relationships: occurrence and effect of the parasitic isopod Mothocya epimerica Costa, 1851 (Isopoda: Flabellifera: Cymothoidae) on sand smelt Atherina boyeri Risso, 1810 (Osteichthyes: Atherinidae), in the Mesolongi and Etolikon lagoons (W. Greece). Dis Aquat Org 54:243-251

Marks R, Juanes F, Hare J, Conover D (1996) Occurrence and effect of the parasitic isopod Lironeca ovalis (Isopoda: Cymothoidae) on young-of-the-year bluefish, Pomatomus saltatrix (Pisces: Pomatomidae). Can J Fish Aquat Sci 53: 2052-2057

Montalenti G (1948) Note sulla sistematica e la biologia di alcuni Cimotoidi del golfo di Napoli (Gen. Emetha, Meinertia, Mothocya Anilocra, Nerocila). Arch Oceanogr Limnol 1-3:25-81

Palmer C, Culley M (1983) Aspects of the biology of the sandsmelt Atherina boyeri Risso, 1810 (Teleostei: Atherinidae) at Oldbury-upon-Severn, Gloucestershire, England. Estuar Coast Shelf Sci 16:163-172

Palmer CJ, Culley BM, Claridge NP (1979) A further occurrence of Atherina boyeri Risso, 1810 in north-eastern Atlantic waters. Environ Biol Fishes 4:71-75

Radujkovic B, Romestand B, Trilles JP (1984) Les parasites de la faune Yougoslave. I. Cymothoidae parasites de poissons de la region l'Adriatique meridionale. Acta Adriat 25: 161-181

Sindermann CJ (1990) Principal diseases of marine fish and shellfish, Vol I. Academic Press, London

Trilles JP (1964a) Specificité parasitaire chez les isopods Cymothoidae mediterranné (Note preliminaire). Vie Milieu 15:105-116

Trilles JP (1964b) Note preliminaire sur quelques aspects de la reproduction chez les isopods Cymothoidae Mediterrannéens. Arch Zool Exp Gen 104:127-134

Trilles JP (1968) Recherches sur les isopodes Cymothoidae des côtes françaises. Bionomie et parasitisme (Vol 1) and Biologie générale et sexualité (Vol 2). Thèse, Montpellier

Trilles JP (1969) Recherches sur les isopodes Cymothoidae des côtes françaises. Apercu général et comparatif sur la bionomie et la sexualité de crustacés. Bull Soc Zool Fr 94: 433-445

Trilles JP (1991) Present researches and perspective on Isopoda (Cymothoidae and Gnathiidae) parasites of fishes. (systematics, faunistics, ecology, biology and physiology) Wiadomosci Parazytol 37:141-143

Trilles JP (1994) Les Cymothoidae (Crustacea, Isopoda) du monde (prodrome pour une faune). Stud Mar 21/22:5-288

Williams EH, Williams LB (1982) Mothocya bohlkeorum new species (Isopoda: Cymothoidae) from West Indian cardinalfishes (Apogonidae). J Crustac Biol 2:570-577

Williams LB, Williams EH Jr (1985) Brood pouch release of Anilocra chromis Williams and Williams (Isopoda: Cymothoidae) a parasite of brown chromis, Chromis multilineatus (Guichenot), in the Caribbean. Crustac Int J Crustac Res 49:92-95

Zar JH (1999) Biostatistical analysis, 4th edn. Prentice Hall, Upper Saddle River, NJ

Submitted: September 2, 2003; Accepted: August 24, 2004

Proofs received from author(s): November 9, 2004 